\title{
Hepatic and plasma sex differences in saturated and monounsaturated fatty acids are associated with differences in expression of elongase 6, but not stearoyl-CoA desaturase in Sprague-Dawley rats
}

\author{
Kristin A. Marks • Alex P. Kitson • Ken D. Stark
}

Received: 4 September 2012/ Accepted: 6 November 2012/Published online: 22 November 2012

(C) Springer-Verlag Berlin Heidelberg 2012

\begin{abstract}
Monounsaturated fatty acids (MUFA) have been viewed as either beneficial or neutral with respect to health; however, recent evidence suggests that MUFA may be associated with obesity and cardiovascular disease. Sex differences in MUFA composition have been reported in both rats and humans, but the basis for this sexual dimorphism is unknown. In the current study, enzymes involved in MUFA biosynthesis are examined in rat and cell culture models. Male and female rats were maintained on an AIN93G diet prior to killing at 14 weeks of age after an overnight fast. Concentrations of 16:0 $(2,757 \pm 616$ vs. $3,515 \pm 196 \mu \mathrm{g}$ fatty acid/g liver in males), 18:1n-7 $(293 \pm 66$ vs. $527 \pm 49 \mu \mathrm{g} / \mathrm{g})$ and 18:1n-9 (390 \pm 80 vs. $546 \pm 47 \mu \mathrm{g} / \mathrm{g}$ ) were lower, and concentrations of 18:0 $(5,943 \pm 1,429$ vs. $3,987 \pm 325 \mu \mathrm{g} / \mathrm{g})$ were higher in phospholipids in livers from female rats compared with males. Hepatic elongase $6 \mathrm{mRNA}$ and protein were 5.9- and 2.0-fold higher, respectively, in females compared with males. Stearoyl-CoA desaturase expression did not differ. Specific hormonal effects were examined in HepG2 cells cultured with varying concentrations of $17 \beta$-estradiol, progesterone and testosterone $(0,10,30$ and $100 \mathrm{nM})$ for $72 \mathrm{~h}$. Progesterone and $17 \beta$-estradiol treatments increased, while testosterone decreased, elongase 6 protein. Sex differences in MUFA composition were associated with increased expression of hepatic elongase 6 in females relative to male rats, which appears to be mediated by sex hormones based on observations of hormonal treatments of HepG2 cells.
\end{abstract}

K. A. Marks · A. P. Kitson · K. D. Stark (ه)

Laboratory of Nutritional and Nutraceutical Research,

Department of Kinesiology, University of Waterloo,

Waterloo, ON N2L 3G1, Canada

e-mail:kstark@uwaterloo.ca
Keywords Elongase - Sex differences .

Monounsaturated fatty acids · Desaturase $\cdot$ Estrogen

\section{Introduction}

Monounsaturated fatty acids (MUFA) are generally thought of as beneficial for health, especially when replacing carbohydrates and saturated fats in the diet (Lecerf 2009; Baum et al. 2012; Gillingham et al. 2011; Hu et al. 1997). However, recent evidence suggests that there may be controversy regarding the n-7 family of MUFA, as recent reports have linked high levels of 16:1n-7 and 18:1n-7 to cardiovascular disease (Djousse et al. 2012; Wu et al. 2011). While much of these effects have been studied with regard to dietary MUFA, endogenously synthesized MUFA have been implicated in the development of obesity and insulin resistance (Flowers and Ntambi 2009). MUFA synthesized de novo are preferred substrates for hepatic triacylglycerol synthesis (Shimomura et al. 1998; Man et al. 2006). In addition to triacylglycerol synthesis, disruptions of MUFA biosynthesis alter hepatic phospholipid and cholesteryl ester synthesis and fatty acid content (Miyazaki et al. 2001). These perturbations have the potential to influence lipoprotein metabolism and cell membrane structure. De novo lipogenesis as measured by isotopic enrichment of VLDL palmitate and 16:1n-7 content in plasma phospholipids is associated with hypertriglyceridemia and insulin resistance in human populations (Schwarz et al. 2003; Mozaffarian et al. 2010).

Sex differences in the concentration of MUFA have been reported in humans (Marangoni et al. 2007) and rodents (Burdge et al. 2008; Extier et al. 2010), with 18: 1n-9 being higher in male whole blood (Marangoni et al. 2007) and rat liver phospholipids (Burdge et al. 2008; 
Extier et al. 2010). MUFA are normally incorporated into phospholipids and neutral lipids (Paton and Ntambi 2009) and oxidized for energy (Bergouignan et al. 2009). MUFA can be synthesized from saturated fatty acids by the action of stearoyl-CoA desaturase (SCD), the rate-limiting enzyme in MUFA synthesis (Miyazaki and Ntambi 2003) (Fig. 1). In both animal and human studies, SCD expression and activity are associated with obesity and the development of the metabolic syndrome (Garcia-Serrano et al. 2011; Ntambi et al. 2002; Bjermo and Riserus 2010). Estrogen appears to negatively regulate SCD mRNA activity in rodents and may mediate the sex differences in MUFA content. A greater understanding of the role of sex and sex hormones on the biosynthesis of MUFA is required.

The liver plays a central role in fatty acid metabolism, triacylglycerol synthesis and energy homeostasis (Guillou et al. 2008). SCD1 is the main isoform of SCD in the liver of humans and rodents, though SCD2 has been identified in mice and rats (Miyazaki et al. 2006) and SCD5 has been identified in humans (Wang et al. 2005a). The preferred substrate of SCD1 is 18:0 (Miyazaki et al. 2006), which is desaturated to produce $18: 1 \mathrm{n}-9$. Palmitate is also a substrate of SCD1, but the affinity for this fatty acid is not as high (Hudgins et al. 1996). In addition, fatty acid synthase which synthesizes palmitate de novo and elongase 6 which preferentially elongates saturated fatty acids (SFA) and MUFA are involved in MUFA biosynthesis and elongation (Fig. 1) (Green et al. 2010). Elongase 5 is relatively less active toward SFA and MUFA compared with polyunsaturated fatty acids (PUFA), but its high expression level in

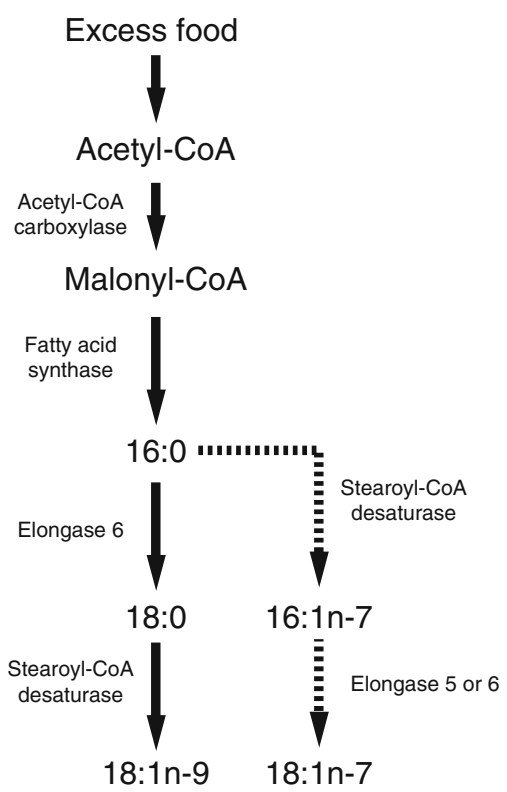

Fig. 1 Enzymes involved in de novo fatty acid synthesis. Solid arrows indicate dominant pathway, while dashed line indicates the alternate pathway the liver (Wang et al. 2005b) indicates that it is likely involved in hepatic SFA and MUFA metabolism (Green et al. 2010).

Understanding the regulation of MUFA biosynthesis and what role sex hormones play in MUFA metabolism can provide insight on the role of MUFA in health. Previous studies examining sex differences in hepatic expression of SCD1 and elongase 6 have not been measured at both the mRNA and protein levels, and to our knowledge, no one has examined what role sex hormones play in the regulation of protein expression of these enzymes. Therefore, the goal of the present study is to characterize the effect of sex and gonadal hormones on plasma, erythrocyte and liver MUFA content and the hepatic expression of SCD1, elongase 5 and 6 , fatty acid synthase, SCD2 and acetylCoA carboxylase using rat and cell culture models.

\section{Materials and methods}

Animals

All animal experiments were carried out according to guidelines of the University of Waterloo Animal Care Committee and Canadian Council on Animal Care. Tenweek-old male and female Sprague-Dawley rats $(n=6$ each) (Harlan Laboratories, Mississauga, ON) were housed 3 per cage in the Department of Kinesiology at the University of Waterloo with a reversed 12:12-h light-dark cycle. The temperature was maintained at $21 \pm 1{ }^{\circ} \mathrm{C}$. Rats had ad libitum access to food (AIN-93G diet, Harlan Laboratories) and water. At 14 weeks of age, animals were fasted overnight and killed via cardiocentesis after sedation by intraperitoneal sodium pentobarbital injection. Blood was collected by cardiocentesis into an EDTA-containing syringe, and plasma was isolated by centrifugation at $1,500 \mathrm{~g}$, and stored at $-80{ }^{\circ} \mathrm{C}$. Tissues were quickly excised, washed in saline $(0.9 \% \mathrm{NaCl}, \mathrm{w} / \mathrm{v})$ and frozen in liquid nitrogen, prior to storage at $-80{ }^{\circ} \mathrm{C}$.

HepG2 cells supplemented with $17 \beta$-estradiol, progesterone and testosterone

HepG2 cells were grown in low-glucose Dulbecco's modified Eagle's medium, supplemented with $10 \%$ FBS, $100 \mathrm{U} / \mathrm{mL}$ penicillin and $100 \mathrm{mg} / \mathrm{mL}$ streptomycin, in a sterile incubator kept at $37{ }^{\circ} \mathrm{C}$ and $5 \% \mathrm{CO}_{2}$ (Roh et al. 2012). Medium was replenished every 3 days after rinsing with PBS (Voest et al. 1993). All reagents were from Thermo Scientific (Wilmington, DE) unless specified otherwise. Cells were split when $80 \%$ confluence had been reached, by treatment with trypsin. Experiments were performed on cells between passage number 10 and 14 . 
17 $\beta$-estradiol, progesterone (Santa Cruz Biotechnology, Santa Cruz, CA) or testosterone (Sigma-Aldrich, Oakville, $\mathrm{ON}$ ) were dissolved in ethanol and added to the medium to achieve final concentrations of $0,10,30$ and $100 \mathrm{nM}$, with a final volume of ethanol in the medium of $0.05 \%(\mathrm{v} / \mathrm{v})$. Pilot experiments performed in our laboratory and others (Portolesi et al. 2008; Extier et al. 2009) showed that this volume of ethanol did not affect fatty acid composition. Cells were exposed to medium containing either the vehicle or the hormone for $72 \mathrm{~h}$ (Voest et al. 1993). After $72 \mathrm{~h}$, the medium was aspirated and cells were rinsed with phosphate-buffered saline and collected following trypsinization. All samples were stored at $-80{ }^{\circ} \mathrm{C}$ until analysis.

\section{RNA extraction and reverse-transcriptase RT-PCR}

RNA was extracted from rat livers by homogenization in Trizol $^{\circledR}$ reagent (Invitrogen Co, Frederick, MD). Phases were separated by the addition of chloroform. Integrity of the extracted RNA was verified by agarose gel electrophoresis with ethidium bromide. Purity was determined by using the 260/280 ratio on a Nanodrop c2000 (Thermo Scientific, Wilmington, DE). Samples with a 260/280 ratio of 1.90 or greater were used for cDNA synthesis, using a high-capacity cDNA reverse transcription kit (Applied Biosystems, Streetsville, ON) with an MJ mini personal thermal cycler (Biorad Laboratories, Mississauga, ON) programmed cycle of $25^{\circ} \mathrm{C}$ for $10 \mathrm{~min}, 37^{\circ} \mathrm{C}$ for $120 \mathrm{~min}$, $85^{\circ} \mathrm{C}$ for $5 \mathrm{~s}$ and $4{ }^{\circ} \mathrm{C}$ until storage at $-80{ }^{\circ} \mathrm{C}$.

The Primer-BLAST program on the NCBI website was used to design primers for rat sequences of SCD1 (GenBank accession number NM_139192.2, Forward: TGTTCCAGAGGAGGTACTACAAGCC, Reverse: GC AGGAAAGTTTCGCCCCAGC), SCD2 (NM_031841, Forward: TCACACTGGTCCCCTCCTGCAAG, Reverse: CTGTGATGCCCAGGGCGCTGATTAC), Elovl6 (NM_ 134383.2, Forward: CACAGCCTCGGGCTTGTTCGT, Reverse: CTATGGGCCGCCTTCTCGGGA), Elovl5 (NM_ 134382.1, Forward: CTCTCGGGTGGCTGTACTTC, Reverse: AGAGGCCCCTTTCTTGTTGT), acetyl-CoA carboxylase (NM_022193.1, Forward: AGATGCACCTG TACCTTGGG, Reverse: TGACCAGATCAGAGTGCC TG), fatty acid synthase (NM_017332.1, Forward: GGAT GTCAACAAGCCCAAGT, Reverse: CAGAGGAGAA GGCCACAAAG) and $18 \mathrm{~S}$ as the housekeeping gene (M11188, Forward: GATCCATTGGAGGGCAAGTCT, Reverse: AACTGCAGCAACTTTAATATACGCTATT). Primers were ordered from Sigma-Aldrich. Reverse-transcriptase real-time PCR was performed using SYBR Green qPCR mastermix (Applied Biosystems) on an Applied Biosystems 7500 real-time PCR system with software version 1.2.3. The reaction volume was $25 \mu \mathrm{l}$. The program had an initial incubation of $95^{\circ} \mathrm{C}$ for $10 \mathrm{~min}$, followed by 40 cycles of $95^{\circ} \mathrm{C}$ for $15 \mathrm{~s}$ and $60{ }^{\circ} \mathrm{C}$ for $1 \mathrm{~min}$. Following 40 cycles, a dissociation curve was produced by increasing the temperature from 60 to $95{ }^{\circ} \mathrm{C}$ at a rate of $1{ }^{\circ} \mathrm{C}$ per minute. Analysis of data was performed by normalizing the threshold cycle number $(\Delta c t)$ of the gene of interest to the $\Delta \mathrm{ct}$ for the housekeeping gene, $18 \mathrm{~S}$ ribosomal RNA, using the $2^{-\Delta \Delta \text { ct }}$ method and expression male values relative to female values and expressing in arbitrary units.

Immunodetection

Rat liver lysates were prepared in a lysis buffer containing $20 \mathrm{mM}$ Hepes, $5.936 \mathrm{mM} \mathrm{NaCl}, 1.5 \mathrm{mM} \mathrm{MgCl}_{2}, 1 \mathrm{mM}$ DTT, $20 \%$ glycerol (v:v), $0.001 \%$ triton X-100 (v:v) and a complete protease inhibitor (Roche Applied Science, Laval, QC, Canada) (Dupont et al. 2001). Protein was extracted from cell pellets buffer containing $0.25 \mathrm{M}$ sucrose, 0.01 M tris- $\mathrm{HCl}, 0.01 \mathrm{M} \mathrm{MgCl}_{2}, 2.5 \mathrm{M}$ DTT and complete protease inhibitor tablets. Protein content was determined by using a bicinchoninic acid procedure. Twenty $\mu \mathrm{g}$ of protein was resolved on a $12.5 \%$ polyacrylamide gel and transferred to a polyvinylidene fluoride membrane (Bio-Rad Laboratories). The membranes were blocked with $5 \%$ BSA or $5 \%$ non-fat milk powder as appropriate in TBS with $0.5 \%$ (v:v) Tween-20 (TBS-T) at room temperature for $1 \mathrm{~h}$. Membranes were then incubated for $1 \mathrm{~h}$ at room temperature with a primary antibody for SCD1 (Abcam, ab19862, diluted 1:1,500 in $5 \%$ BSA in TBS-T) or Elongase 6 (Abcam, ab69857, 1:1,000 in $5 \%$ milk). Membranes were washed with TBS-T and incubated for $1 \mathrm{~h}$ with horseradish peroxidase-conjugated secondary antibody (anti-mouse or anti-rabbit, Santa Cruz Biotechnology) and washed again. Enhanced chemiluminescence western blotting detection reagents was applied to the membrane (GE Healthcare, Mississauga, ON) to allow visualization of bands on a Chemigenius2 Bioimaging system (Syngene inc., Frederick, MD). Quantification of luminescence was done using Genesnap software version 7.07 (Syngene). Values were normalized to female values or vehicle-treated cells, as appropriate. Equal protein loading and transfer were confirmed using a Ponceau $\mathrm{S}$ stain (Bioshop, Burlington, ON) (Dam et al. 2012; McMillan and Quadrilatero 2011; Romero-Calvo et al. 2010).

Fatty acid analysis

Extraction of lipids from liver tissue was done based on the method of Bligh and Dyer (Bligh and Dyer 1959), and erythrocytes using a modified method of Reed (Reed et al. 1960; Metherel et al. 2009), using 2:2:1.8 chloroform:methanol:water (v:v:v) for extraction. Plasma and 
HepG2 lipids were extracted as described by Folch, Lees and Sloane Stanley using 2:1 chloroform:methanol (v:v) (Folch et al. 1957). Butylated hydroxytoluene was included in the extraction reagents to prevent oxidation. For fatty acid composition of total lipids, ethyl docosatrienoate (22:3n-3 ethyl ester, Nu-Chek Prep Inc, Elysian, MN) was included as an internal standard. For fatty acid composition of triacylglycerols and phospholipids, triheptadecanoate (T-155 Nu-Chek Prep) and 1,2-diheptadecanoyl-sn-glycerol-3-phosphocholine (850360P, Avanti Polar Lipids Inc, Alabaster, AL) were included as internal standards. Triacylglycerols and phospholipids were isolated from total lipid extracts by thin layer chromatography using $20 \times 20 \mathrm{~cm}$ plates with a $60 \AA$ silica gel layer (Whatman International LTD, Maidstone, England) and 60:40:2 heptane:diethyl ether:acetic acid (v:v:v) as the mobile phase (Christie 1989). Triacylglycerol and phospholipid bands were visualized under UV light with 2,7-dichlorofluorescein (Sigma-Aldrich, Oakville, ON) and identified by comparison to a reference standard.

Total lipid extracts, triacylglycerols and phospholipids were transesterified by $14 \% \mathrm{BF}_{3}$ in methanol at $85{ }^{\circ} \mathrm{C}$ for $1 \mathrm{~h}$ to produce fatty acid methyl esters (Morrison and Smith 1964) that were then separated by fast-gas chromatography (Stark and Salem 2005). Peaks were identified by comparison to a reference mixture of fatty acids (GLC-569, $\mathrm{Nu}$-Chek Prep Inc) and quantified relative to the internal standard. Fatty acid results are expressed per gram of liver or erythrocytes, per milliliter of plasma, or per milligram of cellular protein.

\section{Statistical analyses}

All statistical analyses were done by using SPSS for Windows, version 15.0. Independent samples $t$ test was used for comparison between males and females. One-way ANOVA was used for comparison between hormone concentrations in HepG2 cells. Tukey's post hoc test was used following a significant one-way ANOVA result. Significance was inferred when $p<0.05$. Data are presented as mean $\pm \mathrm{SD}$.

\section{Results}

Sex differences in enzyme expression in rat livers

Expression of enzymes involved in hepatic fatty acid synthesis was examined via real-time PCR and western blotting (Figs. 2, 3, respectively). Elongase 5 and SCD2 mRNA were 0.6- and 0.7-fold lower in females as compared with males. No differences were observed in elongase 5 protein (data not shown), and reliable measurement of SCD2 protein levels was not obtained likely due to low expression levels in liver (Moreau et al. 2006), with transcripts of SCD2 mRNA being approximately 1,800 times lower than those of SCD1 (Yamazaki et al. 2012). Elongase 6 mRNA and protein expression were 5.9- and 2.0-fold higher, respectively, in females as compared with males.

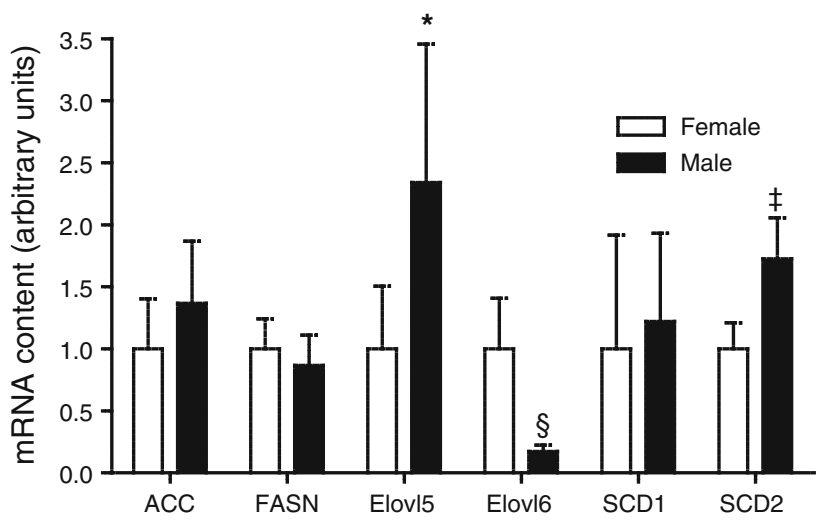

Fig. 2 mRNA content of enzymes involved in de novo fatty acid biosynthesis in the liver of each sex ( $n=6$ for each). Significant sex differences are denoted by $*: p<0.05, \ddagger: p<0.01, \S: p<0.005$, ACC acetyl-CoA carboxylase, FASN fatty acid synthase, Elovl5 elongase 5, Elovl6 elongase 6, SCD1 stearoyl-CoA desaturase-1, $S C D 2$ stearoyl-CoA desaturase 2
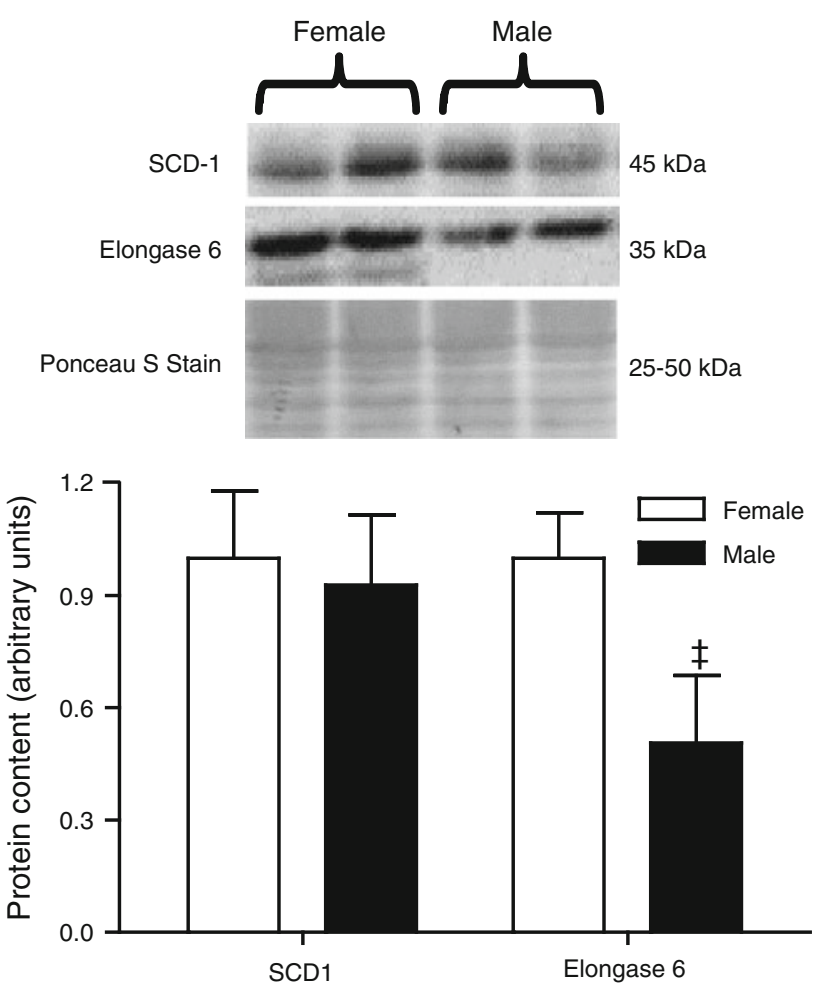

Fig. 3 Densitometric analysis of protein content and representative immunoblots of enzymes involved in MUFA biosynthesis in rat livers $(n=6$ for each sex). Significant sex differences are denoted by $\ddagger$ : $p<0.01$. SCD1 stearoyl-CoA desaturase-1 
No sex differences were observed in acetyl-CoA carboxylase or fatty acid synthase mRNA. No sex differences were observed in SCD1 mRNA or protein.

Sex differences in fatty acid composition of tissues

Sex differences in fatty acid composition in plasma and liver were observed mainly in the phospholipids. Females had significantly lower concentrations of MUFA in liver and plasma phospholipids but not erythrocytes (Table 1). These results largely corresponded to differences in 18:1n-9 concentrations, but females also exhibited lower 16:1n-7 in plasma phospholipids, lower 18:1n-7 in liver phospholipids and erythrocytes and lower 20:1n-9 in liver phospholipids. In addition, 16:0 was significantly lower in both liver and plasma phospholipids of females as compared with males. Conversely, 18:0 was significantly higher in phospholipids in livers and erythrocytes from female rats. The concentration of 18:0 was also higher in the hepatic triacylglycerols of females as compared with males, which was the only sex difference in triacylglycerol fatty acid composition (data not shown). Total hepatic fatty acid concentrations did not differ between the sexes, although there were significant differences between n-3 and n-6 PUFA examined previously (Kitson et al. 2012). Sex differences were not observed in MUFA composition of brain, heart or adipose tissue (data not shown).
Effect of supplemented hormones on protein expression in HepG2 cells

Protein levels of SCD1 in HepG2 cells increased 1.6-fold with $10 \mathrm{nM} 17 \beta$-estradiol and decreased 0.67 -fold with $10 \mathrm{nM}$ progesterone treatment relative to control (Fig. 4). Treatment with 30 and $100 \mathrm{nM}$ of $17 \beta$-estradiol or progesterone had no effect on SCD protein relative to control. Testosterone had no effect on SCD1 at any concentration examined. Elongase 6 protein levels responded to all the hormone treatments. Elongase 6 was increased with 30 and $100 \mathrm{nM} 17 \beta$-estradiol treatment and with $100 \mathrm{nM}$ progesterone treatment, relative to controls. In contrast, treatment with 30 and $100 \mathrm{nM}$ testosterone decreased elongase 6 protein relative to control.

Effect of supplemented hormones on HepG2 cell fatty acid composition

Supplementation of HepG2 cells with $10 \mathrm{nM} 17 \beta$-estradiol increased the concentration of MUFA, SFA, polyunsaturated fatty acids and total fatty acids, specifically in the phospholipids (Table 2). Corresponding increases in the concentrations of individual fatty acids were observed, including 18:1n-7 and 18:1n-9. Supplementation with 30 or $100 \mathrm{nM} 17 \beta$-estradiol had no effect on fatty acid

Table 1 Fatty acid composition of liver phospholipids, plasma phospholipids and erythrocytes of male and female rats fed AIN-93G diet

\begin{tabular}{|c|c|c|c|c|c|c|}
\hline \multirow[t]{2}{*}{ Fatty acid } & \multicolumn{2}{|c|}{$\begin{array}{l}\text { Liver phospholipids ( } \mu \text { g fatty acid/g } \\
\text { liver) }\end{array}$} & \multicolumn{2}{|c|}{$\begin{array}{l}\text { Plasma phospholipids ( } \mu \text { g fatty acid } / \mathrm{ml} \\
\text { plasma) }\end{array}$} & \multicolumn{2}{|c|}{$\begin{array}{l}\text { Erythrocytes ( } \mu \text { g fatty acid } / g \\
\text { erythrocytes) }\end{array}$} \\
\hline & Males & Females & Males & Females & Males & Females \\
\hline $14: 0$ & $31 \pm 8$ & $28 \pm 9$ & N.D. & N.D. & $24 \pm 9$ & $27 \pm 14$ \\
\hline $16: 0$ & $3,515 \pm 196$ & $2,757 \pm 616^{*}$ & $90 \pm 6$ & $64 \pm 11^{\S}$ & $672 \pm 61$ & $615 \pm 83$ \\
\hline 18:0 & $3,987 \pm 325$ & $5,943 \pm 1,429^{\dagger}$ & $85 \pm 6$ & $137 \pm 62$ & $406 \pm 29$ & $548 \pm 37^{\S}$ \\
\hline $20: 0$ & $16 \pm 2$ & $15 \pm 2$ & $0.67 \pm 0.07$ & $0.67 \pm 0.21$ & $4.9 \pm 0.9$ & $5.9 \pm 1.4$ \\
\hline $22: 0$ & $36 \pm 6$ & $38 \pm 6$ & $1.8 \pm 0.2$ & $2.1 \pm 0.4$ & $8.4 \pm 1.4$ & $11.1 \pm 0.9^{\dagger}$ \\
\hline $24: 0$ & $92 \pm 17$ & $110 \pm 16$ & $4.9 \pm 0.3$ & $5.4 \pm 0.9$ & $23 \pm 5$ & $27 \pm 4$ \\
\hline Total SFA & $7,710 \pm 533$ & $8,934 \pm 3,038$ & $184 \pm 11$ & $211 \pm 72$ & $1,231 \pm 148$ & $1,323 \pm 141$ \\
\hline $14: 1$ & $0.4 \pm 0.3$ & $0.8 \pm 1.1$ & $0.02 \pm 0.03$ & $0.01 \pm 0.03$ & $0.3 \pm 0.2$ & $0.6 \pm 0.4$ \\
\hline $16: 1 n-7$ & $45 \pm 11$ & $34 \pm 10$ & $0.66 \pm 0.14$ & $0.46 \pm 0.14 *$ & $7.8 \pm 3.2$ & $5.5 \pm 1.3$ \\
\hline $18: 1 n-7$ & $527 \pm 49$ & $293 \pm 66^{\S}$ & $6 \pm 3$ & $3 \pm 1$ & $61 \pm 3$ & $49 \pm 5^{*}$ \\
\hline $18: 1 n-9$ & $546 \pm 47$ & $390 \pm 80^{\dagger}$ & $8.2 \pm 1.2$ & $5.6 \pm 1.4^{\dagger}$ & $156 \pm 14$ & $137 \pm 20$ \\
\hline $20: 1 n-9$ & $25 \pm 5$ & $12 \pm 2^{\S}$ & $0.42 \pm 0.04$ & $0.18 \pm 0.05^{\S}$ & $3.5 \pm 0.6$ & $3.4 \pm 0.9$ \\
\hline $22: 1 n-9$ & $5.6 \pm 2.3$ & $6.2 \pm 1.8$ & $0.30 \pm 0.06$ & $0.30 \pm 0.03$ & $7.7 \pm 1.6$ & $9.8 \pm 4.6$ \\
\hline $24: 1 n-9$ & $26 \pm 3$ & $30 \pm 4$ & $3 \pm 0.3$ & $3 \pm 0.6$ & $14.0 \pm 1.7$ & $14.8 \pm 1.3$ \\
\hline Total MUFA & $1,177 \pm 100$ & $766 \pm 159^{\S}$ & $18 \pm 3$ & $13 \pm 3^{\dagger}$ & $251 \pm 17$ & $221 \pm 24$ \\
\hline Total n-6 PUFA & $7,823 \pm 643$ & $7,262 \pm 1,664^{*}$ & $120 \pm 10$ & $98 \pm 21$ & $1,268 \pm 182$ & $1,141 \pm 132$ \\
\hline Total n-3 PUFA & $1,284 \pm 134$ & $2,096 \pm 346^{\S}$ & $11 \pm 2$ & $14 \pm 4$ & $122 \pm 11$ & $141 \pm 8$ \\
\hline Total fatty acids & $18,406 \pm 1,183$ & $19,391 \pm 4,242$ & $332 \pm 18$ & $335 \pm 95$ & $3,001 \pm 159$ & $2,978 \pm 166$ \\
\hline
\end{tabular}

Data are mean \pm SD from three determinations of fatty acid concentrations ( $n=6$ for each sex)

Significant sex differences are denoted by $* p<0.05,{ }^{\dagger} p<0.01,{ }^{*} p<0.005,{ }^{\S} p<0.001$ 

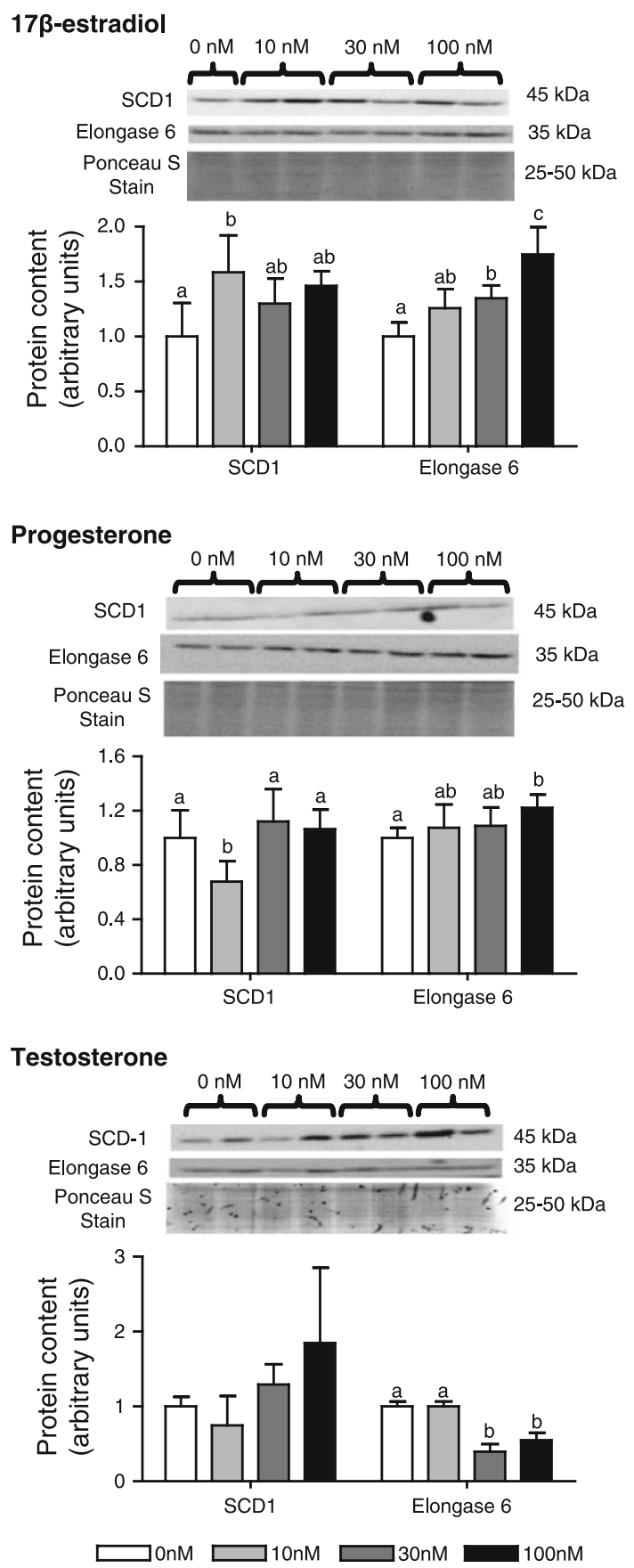

Fig. 4 Densitometric analysis of protein content and representative immunoblots of enzymes involved in MUFA biosynthesis in HepG2 cells treated with varying concentrations of a $17 \beta$-estradiol, b progesterone and $\mathbf{c}$ testosterone ( $n=5$ for each group). Groups with different superscripts are significantly different by Tukey's post hoc test $(p<0.05)$ following significant $F$ value by one-way ANOVA. $S C D 1$ stearoyl-CoA desaturase 1

concentration relative to control. Progesterone supplementation had no effect on HepG2 fatty acid composition (results not shown). Treatment with $30 \mathrm{nM}$ testosterone resulted in a significant increase of $16: 1 \mathrm{n}-7$ in total lipids as compared to $0 \mathrm{nM}(14 \pm 1.2$ vs. $10.7 \pm 0.7 \mu \mathrm{g}$ fatty acid/ mg cellular protein), with 10 and $100 \mathrm{nM}$ being intermediate $(12 \pm 1.2$ and $12.8 \pm 1.5 \mu \mathrm{g}$ fatty acid/mg cellular protein, respectively).

\section{Discussion}

We hypothesized that males would have higher SCD1 expression and consequently higher liver and blood MUFA concentrations than females. In the current study, there was a shift toward lower 18:0 and higher 16:0, 16:1n-7, 18:1n-7 and 18:1n-9 in males as compared with females that were relatively consistent with previous studies (Burdge et al. 2008; Extier et al. 2010). Treatment of HepG2 cells with $10 \mathrm{nM} \mathrm{17 \beta -estradiol} \mathrm{resulted} \mathrm{in} \mathrm{significant} \mathrm{increases} \mathrm{in}$ both n-7 and n-9 MUFA species, but the relative percentage of these fatty acids did not change as the concentration of total fatty acids also increased, suggesting nonspecific lipogenesis. Despite the differences in enzyme expression, these fatty acid differences were not present at 30 and $100 \mathrm{nM} 17 \beta$-estradiol treatments, possibly due to the variable effects of $17 \beta$-estradiol on fatty acid oxidation (Gower et al. 2002; Toda et al. 2001; Campbell et al. 2003) or feedback inhibition of estradiol on estrogen receptors, which has been shown previously to occur in other species and tissues (Chandrasekar et al. 2010; Anwar et al. 2001). Total fatty acid concentrations did not differ between the male and female rats, and a lack of sex difference in the mRNA expression of fatty acid synthase and acetyl-CoA carboxylase also suggests that sex differences in rat tissue SFA and MUFA are independent of general de novo fatty acid synthesis.

The sex differences and hormonal treatment responses were consistent for elongase 6 expression. Both the mRNA and protein levels were higher in females as compared with males, and the higher concentrations of 18:0 and lower concentrations of 16:0 in liver phospholipids of females may be an indirect indicator of elongase 6 activity. Both estrogen and progesterone treatment of HepG2 cells increased elongase 6 expression, while testosterone treatment decreased expression. The higher concentrations of the $\mathrm{n}-7$ family of MUFA in males may also be related to the lower elongase 6 expression in males, as higher 16:0 concentrations and lower 18:0 concentrations could result in more 16:0 being desaturated prior to elongation (Hudgins et al. 1996; Miyazaki et al. 2006). The preference of elongase 6 for 16:0 as a substrate is well established. Elongase 6 knockout mice show increased concentrations of 16:0 and 16:1n-7, and lower concentrations of 18:0 and $18: 1 \mathrm{n}-9$, as compared with wild-type mice (Matsuzaka et al. 2007). When fed a high-fat diet, elongase 6 knockout mice and wild-type mice both develop hepatosteatosis; 
Table 2 Phospholipid fatty acid composition of HepG2 cells incubated with varying supplemented concentrations of $17 \beta$-estradiol for $72 \mathrm{~h}$ deviation, $n=5$ per group

Values with different superscripts are significantly different by Tukey's post hoc test $(p<0.05)$ following significant $F$ value by one-way ANOVA

\begin{tabular}{lcccc}
\hline Fatty acid & \multicolumn{3}{l}{$\mu \mathrm{g}$ fatty acid/mg cellular protein } & \\
\cline { 2 - 5 } & $0 \mathrm{nM}$ & $10 \mathrm{nM}$ & $30 \mathrm{nM}$ & $100 \mathrm{nM}$ \\
\hline $12: 0$ & $0.12 \pm 0.05$ & $0.18 \pm 0.07$ & $0.11 \pm 0.03$ & $0.15 \pm 0.08$ \\
$14: 0$ & $0.86 \pm 0.15$ & $1.00 \pm 0.08$ & $0.87 \pm 0.17$ & $0.91 \pm 0.18$ \\
$16: 0$ & $12 \pm 1^{\mathrm{ab}}$ & $15 \pm 1^{\mathrm{a}}$ & $11 \pm 2^{\mathrm{b}}$ & $12 \pm 2^{\mathrm{ab}}$ \\
$18: 0$ & $5 \pm 1$ & $6 \pm 1$ & $5 \pm 2$ & $5 \pm 1$ \\
$20: 0$ & $0.10 \pm 0.02$ & $0.13 \pm 0.02$ & $0.13 \pm 0.04$ & $0.12 \pm 0.01$ \\
$22: 0$ & $0.16 \pm 0.02$ & $0.16 \pm 0.05$ & $0.15 \pm 0.03$ & $0.15 \pm 0.04$ \\
$23: 0$ & $0.12 \pm 0.01$ & $0.13 \pm 0.04$ & $0.12 \pm 0.03$ & $0.11 \pm 0.02$ \\
$24: 0$ & $0.08 \pm 0.01$ & $0.05 \pm 0.05$ & $0.07 \pm 0.01$ & $0.07 \pm 0.02$ \\
Total SFA & $18 \pm 2$ & $22 \pm 2$ & $18 \pm 4$ & $18 \pm 2$ \\
14:1 & $0.19 \pm 0.03^{\mathrm{ab}}$ & $0.25 \pm 0.02^{\mathrm{a}}$ & $0.17 \pm 0.02^{\mathrm{b}}$ & $0.21 \pm 0.04^{\mathrm{ab}}$ \\
$16: 1 \mathrm{n}-7$ & $3.68 \pm 0.42^{\mathrm{ab}}$ & $4.63 \pm 0.35^{\mathrm{a}}$ & $3.50 \pm 0.61^{\mathrm{b}}$ & $3.70 \pm 0.57^{\mathrm{ab}}$ \\
$18: 1 \mathrm{n}-7$ & $6.33 \pm 0.57^{\mathrm{a}}$ & $7.87 \pm 0.60^{\mathrm{b}}$ & $5.83 \pm 0.86^{\mathrm{a}}$ & $6.19 \pm 0.92^{\mathrm{a}}$ \\
18:1n-9 & $8.34 \pm 0.72^{\mathrm{a}}$ & $10.46 \pm 0.63^{\mathrm{b}}$ & $7.60 \pm 0.98^{\mathrm{a}}$ & $8.18 \pm 1.43^{\mathrm{a}}$ \\
$20: 1 \mathrm{n}-9$ & $0.18 \pm 0.03$ & $0.21 \pm 0.04$ & $0.16 \pm 0.04$ & $0.16 \pm 0.02$ \\
$22: 1 \mathrm{n}-9$ & $0.27 \pm 0.20$ & $0.34 \pm 0.20$ & $0.22 \pm 0.20$ & $0.36 \pm 0.28$ \\
$24: 1 \mathrm{n}-9$ & $0.18 \pm 0.01$ & $0.19 \pm 0.05$ & $0.17 \pm 0.04$ & $0.17 \pm 0.06$ \\
Total MUFA & $19 \pm 2^{\mathrm{a}}$ & $24 \pm 1^{\mathrm{b}}$ & $18 \pm 2^{\mathrm{a}}$ & $19 \pm 3^{\mathrm{a}}$ \\
Total n-6 PUFA & $3.29 \pm 0.37^{\mathrm{ab}}$ & $3.96 \pm 0.36^{\mathrm{a}}$ & $3.03 \pm 0.43^{\mathrm{b}}$ & $3.17 \pm 0.53^{\mathrm{ab}}$ \\
Total n-3 PUFA & $1.4 \pm 0.17^{\mathrm{ab}}$ & $1.67 \pm 0.13^{\mathrm{a}}$ & $1.28 \pm 0.20^{\mathrm{b}}$ & $1.33 \pm 0.21^{\mathrm{ab}}$ \\
Total fatty acids & $48.53 \pm 4.85^{\mathrm{ab}}$ & $59.33 \pm 3.65^{\mathrm{a}}$ & $45.36 \pm 7.70^{\mathrm{b}}$ & $47.78 \pm 7.58^{\mathrm{ab}}$ \\
\hline & & & &
\end{tabular}

however, unlike the wild-type mice, the elongase 6 knockout mice have nearly normal insulin sensitivity (Matsuzaka et al. 2007). Conversely, accumulation of 18:0 and 18:1n-9 occurs in elongase 6 overexpression (Green et al. 2010). Elongase 6 expression is higher in Zucker obese rats as compared with lean littermates (Fevre et al. 2011) and has been shown to modulate inflammation, oxidative stress and fibrosis in the liver when fed a high-fat diet, as well as being positively correlated to hepatosteatosis severity (Matsuzaka et al. 2012). These reports highlight the importance of the results of the present study, as sex differences in elongase 6 expression, and evidence that its expression is regulated by estradiol may have implications in human health and the progression of obesity.

There has been a report of higher elongase 6 mRNA expression in males as compared with females (Gustavsson et al. 2010); however, this was in a non-fasted model and elongase 6 is strongly regulated by fasting and refeeding (Matsuzaka et al. 2002; Turyn et al. 2010). Elongase 5 mRNA but not protein was higher in males, suggesting that the mRNA may not be translated into protein, or there is a higher rate of protein turnover in males. Elongase 5 is typically involved in PUFA elongation, but is also known to preferentially elongate 16:1n-7 (Wang et al. 2006), and the higher elongase 5mRNA expression may be in response to the higher levels of n-7 MUFA observed in males.
Contrary to our hypothesis, SCD1 expression did not differ between males and females. In the present experiments with HepG2 cells, SCD1 expression increased with $10 \mathrm{nM} 17 \beta$-estradiol treatment and decreased with $10 \mathrm{nM}$ progesterone treatment but higher concentrations had no effect. Treatment with testosterone had no effect on SCD1 at any concentration. SCD1 expression is higher in both ovariectomized rats (Alessandri et al. 2011; Paquette et al. 2008) and estrogen receptor alpha knockout mice (Bryzgalova et al. 2008) as compared with appropriate controls. Higher hepatic SCD1 expression in male as compared with female rats has also been reported previously (Gustavsson et al. 2010), but the results were generated from a whole genome microarray of mRNA, whereas we performed targeted quantitative RT-PCR to assess mRNA and immunoblot to assess protein expression. In addition, differences in sexual maturity may contribute to the different results, as the rats in the previous study were 7 weeks of age, and in the current study, the rats were 14 weeks of age. First estrous of Sprague-Dawley rats occurs between 36 and 45 days (Merry and Holehan 1979). Hepatic SCD2 mRNA expression was higher in males but SCD2 protein could not be reliably measured (Moreau et al. 2006; Yamazaki et al. 2012). The higher expression of SCD2 in males suggests that it may be involved in the increased MUFA concentrations observed in males, including higher concentrations of $18: 1 \mathrm{n}-9$, which was higher in males 
Fig. 5 The role of stearoylCoA desaturase and elongase 6 on the observation of decreased "SCD activity index" (18:1n-9/ 18:0) in female rats as compared with male rats. a Usual interpretation. b Interpretation based after considering gene expression assessments
A Stearoyl-CoA desaturase mediatation

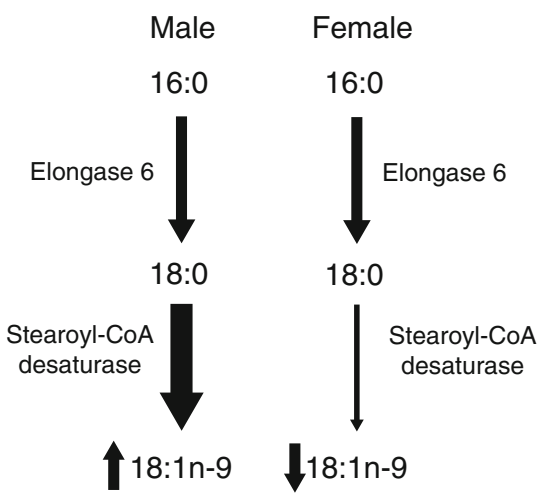

\section{B Elongase 6 mediation}

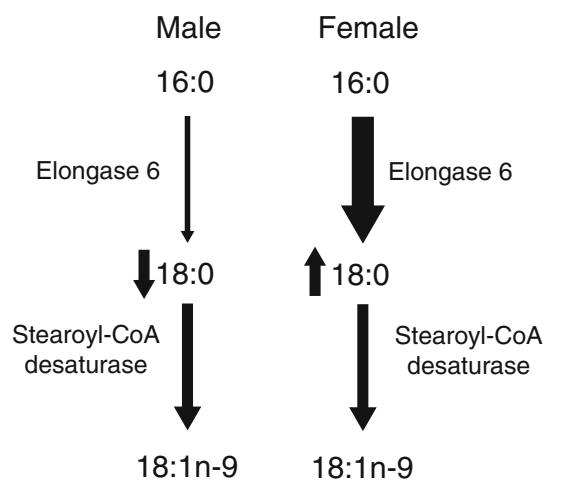

despite lower 18:0 concentrations, but this SCD isoform has not been identified in humans (Wang et al. 2005a) and therefore could not be measured in the HepG 2 cell culture experiments. Future research is required to determine the role of SCD2 on MUFA metabolism in rats. As SCD1 activity was not measured in the present study, it is unclear whether there were differences in activity that may contribute to higher $18: 1 n-9$ concentrations in males. In addition, the use of metabolic tracers to elucidate the mechanism behind the observed differences in MUFA composition and assays of enzyme activity are needed.

The sex differences observed herein are limited to a fasting rodent model, and extrapolation to the fed state or to sex differences in fatty acid composition of humans requires specific considerations. Many genes involved in fatty acid biosynthesis including SCD1 and elongase 6 are strongly regulated by fasting and refeeding (Turyn et al. 2010; Zhang et al. 2011). While overnight fasting is typically preferred to ad libitum food access prior to killing to reduce inter-individual variation, experiments examining fasting and controlled feeding protocol prior to killing need to be considered for future studies. In humans, sex differences in macronutrient preferences may also contribute to differences in SFA and MUFA compositions, as well as influence hepatic gene expression. While the male and female rats in the present study were fed the same controlled chow diets, human diets are not regulated. Women tend to consume higher proportions of carbohydrates and less fat as compared with men (Garriguet 2007; Metherel et al. 2009). A high carbohydrate and low fat diet can result in an increased influence of endogenous fatty acid synthesis on tissue fatty acid composition (Lands 1995). Specifically, palmitate production is increased that results in increased incorporation of palmitate into tissue lipids, and increased desaturation of palmitate by SCD1 generating $\mathrm{n}-7$ fatty acids. The $\mathrm{n}-7$ fatty acid content of complex lipids typically increase with the potential for decreases in fatty acids derived solely from the diet. Future work examining the effect of diet manipulations on sex differences in MUFA metabolism is required.

To our knowledge, this is the first study to report sex differences in elongase $6 \mathrm{mRNA}$ and protein expression, a novel insight into MUFA metabolism. As sex differences were observed in SFA and MUFA in the present study without sex differences in SCD1 expression, it appears that elongase 6 may have a major influence on MUFA biosynthesis. This is particularly relevant given the use of the ratio of $18: 1 n-9$ to $18: 0$ and $16: 1 n-7$ to $16: 0$, as indicators of SCD expression, without directly measuring SCD mRNA or protein levels (Saito et al. 2011; Stefan et al. 2008; Attie et al. 2002; Extier et al. 2010). This "SCD activity index" is strongly associated with obesity (GarciaSerrano et al. 2011; Chu et al. 2006) and cardiovascular disease (Warensjo et al. 2008). The use of ratios of fatty acids to indicate enzyme activities involved in biosynthesis is common, but it is generally an oversimplification that ignores the influence of other enzymes involved in biosynthesis, the selective incorporation of fatty acids into more complex lipids and fatty acid oxidation. In the current study, the 18:1n-9/18:0-based hepatic SCD activity index in females was approximately $50 \%$ of that in males. This was as a result of higher 18:0 concentrations in females likely due to higher expression of elongase 6 rather than sex differences in $18: \ln 9$ levels mediated by SCD1 (Fig. 5).

In conclusion, 16:0 and several MUFA species, 16:1n-7, 18:1n-7 and 18:1n-9, were significantly higher in phospholipids in livers of male rats, despite no differences in hepatic SCD1 expression. These results indicate that the commonly used SCD activity index may not be the most accurate indicator of SCD protein in some cases. In females, 18:0 was significantly higher in liver phospholipids, corresponding to an increase in elongase 6 expression. Treatment of HepG2 cells with $17 \beta$-estradiol, progesterone and testosterone confirms these results, as female sex hormones had a positive effect on elongase 6 protein expression, and testosterone treatment resulted in 
lower protein expression. However, as some of the expected fatty acid differences were not observed in HepG2 cells, a rat hepatic cell line should be considered for future experiments. Sex differences in tissue MUFA exist and appear to be mediated largely by elongase 6 expression, while the role of SCD1 remains to be elucidated.

Acknowledgments This work was supported by grants from Canada Foundation for Innovation, Natural Sciences and Engineering Research Council of Canada, and the Government of Ontario.

Conflict of interest None.

\section{References}

Alessandri JM, Extier A, Al-Gubory KH, Langelier B, Baudry C, LePoupon C, Lavialle M, Guesnet P (2011) Ovariectomy and 17beta-estradiol alter transcription of lipid metabolism genes and proportions of neo-formed n-3 and n- 6 long-chain polyunsaturated fatty acids differently in brain and liver. J Nutr Biochem 22:820-827

Anwar A, McTernan PG, Anderson LA, Askaa J, Moody CG, Barnett AH, Eggo MC, Kumar S (2001) Site-specific regulation of oestrogen receptor-alpha and -beta by oestradiol in human adipose tissue. Diabetes Obes Metab 3:338-349

Attie AD, Krauss RM, Gray-Keller MP, Brownlie A, Miyazaki M, Kastelein JJ, Lusis AJ, Stalenhoef AF, Stoehr JP, Hayden MR, Ntambi JM (2002) Relationship between stearoyl-CoA desaturase activity and plasma triglycerides in human and mouse hypertriglyceridemia. J Lipid Res 43:1899-1907

Baum SJ, Kris-Etherton PM, Willett WC, Lichtenstein AH, Rudel LL, Maki KC, Whelan J, Ramsden CE, Block RC (2012) Fatty acids in cardiovascular health and disease: a comprehensive update. J Clin Lipidol 6:216-234

Bergouignan A, Momken I, Schoeller DA, Simon C, Blanc S (2009) Metabolic fate of saturated and monounsaturated dietary fats: the Mediterranean diet revisited from epidemiological evidence to cellular mechanisms. Prog Lipid Res 48:128-147

Bjermo H, Riserus U (2010) Role of hepatic desaturases in obesityrelated metabolic disorders. Curr Opin Clin Nutr Metab Care 13:703-708

Bligh EG, Dyer WJ (1959) A rapid method of total lipid extraction and purification. Can J Biochem Physiol 37:911-917

Bryzgalova G, Lundholm L, Portwood N, Gustafsson JA, Khan A, Efendic S, Dahlman-Wright K (2008) Mechanisms of antidiabetogenic and body weight-lowering effects of estrogen in highfat diet-fed mice. Am J Physiol Endocrinol Metab 295:E904E912

Burdge GC, Slater-Jefferies JL, Grant RA, Chung WS, West AL, Lillycrop KA, Hanson MA, Calder PC (2008) Sex, but not maternal protein or folic acid intake, determines the fatty acid composition of hepatic phospholipids, but not of triacylglycerol, in adult rats. Prostaglandins Leukot Essent Fatty Acids 78:73-79

Campbell SE, Mehan KA, Tunstall RJ, Febbraio MA, Cameron-Smith D (2003) 17beta-estradiol upregulates the expression of peroxisome proliferator-activated receptor alpha and lipid oxidative genes in skeletal muscle. J Mol Endocrinol 31:37-45

Chandrasekar G, Archer A, Gustafsson JA, Andersson LM (2010) Levels of 17beta-estradiol receptors expressed in embryonic and adult zebrafish following in vivo treatment of natural or synthetic ligands. PLoS ONE 5:e9678
Christie WW (1989) Gas chromatography and lipids. The Oily Press, Ayr

Chu K, Miyazaki M, Man WC, Ntambi JM (2006) Stearoyl-coenzyme A desaturase 1 deficiency protects against hypertriglyceridemia and increases plasma high-density lipoprotein cholesterol induced by liver $\mathrm{X}$ receptor activation. Mol Cell Biol 26:6786-6798

Dam AD, Mitchell AS, Rush JW, Quadrilatero J (2012) Elevated skeletal muscle apoptotic signaling following glutathione depletion. Apoptosis 17:48-60

Djousse L, Matthan NR, Lichtenstein AH, Gaziano JM (2012) Red blood cell membrane concentration of cis-palmitoleic and cisvaccenic acids and risk of coronary heart disease. Am J Cardiol 110:539-544

Dupont J, Fernandez AM, Glackin CA, Helman L, LeRoith D (2001) Insulin-like growth factor 1 (IGF-1)-induced twist expression is involved in the anti-apoptotic effects of the IGF-1 receptor. J Biol Chem 276:26699-26707

Extier A, Perruchot MH, Baudry C, Guesnet P, Lavialle M, Alessandri JM (2009) Differential effects of steroids on the synthesis of polyunsaturated fatty acids by human neuroblastoma cells. Neurochem Int 55:295-301

Extier A, Langelier B, Perruchot MH, Guesnet P, Van Veldhoven PP, Lavialle M, Alessandri JM (2010) Gender affects liver desaturase expression in a rat model of n-3 fatty acid repletion. J Nutr Biochem 21:180-187

Fevre C, Bellenger S, Pierre AS, Minville M, Bellenger J, Gresti J, Rialland M, Narce M, Tessier C (2011) The metabolic cascade leading to eicosanoid precursors-desaturases, elongases, and phospholipases A2-is altered in Zucker fatty rats. Biochim Biophys Acta 1811:409-417

Flowers MT, Ntambi JM (2009) Stearoyl-CoA desaturase and its relation to high-carbohydrate diets and obesity. Biochim Biophys Acta 1791:85-91

Folch J, Lees M, Sloane Stanley GHS (1957) A simple method for the isolation and purification of total lipides from animal tissues. J Biol Chem 226:497-509

Garcia-Serrano S, Moreno-Santos I, Garrido-Sanchez L, GutierrezRepiso C, Garcia-Almeida JM, Garcia-Arnes J, Rivas-Marin J, Gallego-Perales JL, Garcia-Escobar E, Rojo-Martinez G, Tinahones F, Soriguer F, Macias-Gonzalez M, Garcia-Fuentes E (2011) Stearoyl-CoA desaturase-1 is associated with insulin resistance in morbidly obese subjects. Mol Med 17:273-280

Garriguet D (2007) Canadians' eating habits. Health Rep 18:17-32

Gillingham LG, Harris-Janz S, Jones PJ (2011) Dietary monounsaturated fatty acids are protective against metabolic syndrome and cardiovascular disease risk factors. Lipids 46:209-228

Gower BA, Nagy TR, Blaylock ML, Wang C, Nyman L (2002) Estradiol may limit lipid oxidation via Cpt 1 expression and hormonal mechanisms. Obes Res 10:167-172

Green CD, Ozguden-Akkoc CG, Wang Y, Jump DB, Olson LK (2010) Role of fatty acid elongases in determination of de novo synthesized monounsaturated fatty acid species. J Lipid Res 51:1871-1877

Guillou H, Martin PG, Pineau T (2008) Transcriptional regulation of hepatic fatty acid metabolism. Subcell Biochem 49:3-47

Gustavsson C, Yassin K, Wahlstrom E, Cheung L, Lindberg J, Brismar K, Ostenson CG, Norstedt G, Tollet-Egnell P (2010) Sex-different hepaticglycogen content and glucose output in rats. BMC Biochem 11:38

Hu FB, Stampfer MJ, Manson JE, Rimm E, Colditz GA, Rosner BA, Hennekens CH, Willett WC (1997) Dietary fat intake and the risk of coronary heart disease in women. N Engl J Med 337:1491-1499

Hudgins LC, Hellerstein M, Seidman C, Neese R, Diakun J, Hirsch J (1996) Human fatty acid synthesis is stimulated by a eucaloric low fat, high carbohydrate diet. J Clin Invest 97:2081-2091 
Kitson AP, Smith TL, Marks KA, Stark KD (2012) Tissue-specific sex differences in docosahexaenoic acid and Delta6-desaturase in rats fed a standard chow diet. Appl Physiol Nutr Metab $37: 1200-1211$

Lands WE (1995) Long-term fat intake and biomarkers. Am J Clin Nutr 61:721S-725S

Lecerf JM (2009) Fatty acids and cardiovascular disease. Nutr Rev 67:273-283

Man WC, Miyazaki M, Chu K, Ntambi J (2006) Colocalization of SCD1 and DGAT2: implying preference for endogenous monounsaturated fatty acids in triglyceride synthesis. J Lipid Res 47:1928-1939

Marangoni F, Colombo C, Martiello A, Negri E, Galli C (2007) The fatty acid profiles in a drop of blood from a fingertip correlate with physiological, dietary and lifestyle parameters in volunteers. Prostaglandins Leukot Essent Fatty Acids 76:87-92

Matsuzaka T, Shimano H, Yahagi N, Yoshikawa T, Amemiya-Kudo M, Hasty AH, Okazaki H, Tamura Y, Iizuka Y, Ohashi K, Osuga J, Takahashi A, Yato S, Sone H, Ishibashi S, Yamada N (2002) Cloning and characterization of a mammalian fatty acyl-CoA elongase as a lipogenic enzyme regulated by SREBPs. J Lipid Res 43:911-920

Matsuzaka T, Shimano H, Yahagi N, Kato T, Atsumi A, Yamamoto $\mathrm{T}$, Inoue $\mathrm{N}$, Ishikawa $\mathrm{M}$, Okada $\mathrm{S}$, Ishigaki $\mathrm{N}$, Iwasaki $\mathrm{H}$, Iwasaki Y, Karasawa T, Kumadaki S, Matsui T, Sekiya M, Ohashi K, Hasty AH, Nakagawa Y, Takahashi A, Suzuki H, Yatoh S, Sone H, Toyoshima H, Osuga J, Yamada N (2007) Crucial role of a long-chain fatty acid elongase, Elovl6, in obesity-induced insulin resistance. Nat Med 13:1193-1202

Matsuzaka T, Atsumi A, Matsumori R, Nie T, Shinozaki H, SuzukiKemuriyama N, Kuba M, Nakagawa Y, Ishii K, Shimada M, Kobayashi K, Yatoh S, Takahashi A, Takekoshi K, Sone H, Yahagi N, Suzuki H, Murata S, Nakamuta M, Yamada N, Shimano H (2012) Elovl6 promotes nonalcoholic steatohepatitis in mice and humans. Hepatology. doi: 10.1002/hep.25932

McMillan EM, Quadrilatero J (2011) Differential apoptosis-related protein expression, mitochondrial properties, proteolytic enzyme activity, and DNA fragmentation between skeletal muscles. Am J Physiol Regul Integr Comp Physiol 300:R531-R543

Merry BJ, Holehan AM (1979) Onset of puberty and duration of fertility in rats fed a restricted diet. J Reprod Fertil 57:253259

Metherel AH, Armstrong JM, Patterson AC, Stark KD (2009) Assessment of blood measures of $n-3$ polyunsaturated fatty acids with acute fish oil supplementation and washout in men and women. Prostaglandins Leukot Essent Fatty Acids 81:23-29

Miyazaki M, Ntambi JM (2003) Role of stearoyl-coenzyme A desaturase in lipid metabolism. Prostaglandins Leukot Essent Fatty Acids 68:113-121

Miyazaki M, Kim YC, Ntambi JM (2001) A lipogenic diet in mice with a disruption of the stearoyl-CoA desaturase 1 gene reveals a stringent requirement of endogenous monounsaturated fatty acids for triglyceride synthesis. J Lipid Res 42:1018-1024

Miyazaki M, Bruggink SM, Ntambi JM (2006) Identification of mouse palmitoyl-coenzyme A Delta9-desaturase. J Lipid Res 47:700-704

Moreau C, Froment P, Tosca L, Moreau V, Dupont J (2006) Expression and regulation of the SCD2 desaturase in the rat ovary. Biol Reprod 74:75-87

Morrison WR, Smith LM (1964) Preparation of fatty acid methyl esters and dimethylacetals from lipids with boron fluoridemethanol. J Lipid Res 4:600-608

Mozaffarian D, Cao H, King IB, Lemaitre RN, Song X, Siscovick DS, Hotamisligil GS (2010) Circulating palmitoleic acid and risk of metabolic abnormalities and new-onset diabetes. Am J Clin Nutr 92:1350-1358
Ntambi JM, Miyazaki M, Stoehr JP, Lan H, Kendziorski CM, Yandell BS, Song Y, Cohen P, Friedman JM, Attie AD (2002) Loss of stearoyl-CoA desaturase-1 function protects mice against adiposity. Proc Natl Acad Sci USA 99:11482-11486

Paquette A, Wang D, Jankowski M, Gutkowska J, Lavoie JM (2008) Effects of ovariectomy on PPAR alpha, SREBP-1c, and SCD-1 gene expression in the rat liver. Menopause 15:1169-1175

Paton CM, Ntambi JM (2009) Biochemical and physiological function of stearoyl-CoA desaturase. Am J Physiol Endocrinol Metab 297:E28-E37

Portolesi R, Powell BC, Gibson RA (2008) Delta6 desaturase mRNA abundance in HepG2 cells is suppressed by unsaturated fatty acids. Lipids 43:91-95

Reed CF, Swisher SN, Marinetti GV, Eden EG (1960) Studies of the lipids of the erythrocyte. I. Quantitative analysis of the lipids of normal human red blood cells. J Lab Clin Med 56:281-289

Roh T, Kwak MY, Kwak EH, Kim DH, Han EY, Bae JY, Bang DY, Lim DS, Ahn IY, Jang DE, Lim SK, Yoo SD, Kwack SJ, Park KL, Lee YJ, Kim KB, Lee J, Kim HS, Lee BM (2012) Chemopreventive mechanisms of methionine on inhibition of benzo(a)pyrene-DNA adducts formation in human hepatocellular carcinoma HepG2 cells. Toxicol Lett 208:232-238

Romero-Calvo I, Ocon B, Martinez-Moya P, Suarez MD, Zarzuelo A, Martinez-Augustin O, de Medina FS (2010) Reversible Ponceau staining as a loading control alternative to actin in Western blots. Anal Biochem 401:318-320

Saito E, Okada T, Abe Y, Kuromori Y, Miyashita M, Iwata F, Hara M, Ayusawa M, Mugishima H, Kitamura Y (2011) Docosahexaenoic acid content in plasma phospholipids and desaturase indices in obese children. J Atheroscler Thromb 18:345-350

Schwarz JM, Linfoot P, Dare D, Aghajanian K (2003) Hepatic de novo lipogenesis in normoinsulinemic and hyperinsulinemic subjects consuming high-fat, low-carbohydrate and low-fat, high-carbohydrate isoenergetic diets. Am J Clin Nutr 77:43-50

Shimomura I, Shimano H, Korn BS, Bashmakov Y, Horton JD (1998) Nuclear sterol regulatory element-binding proteins activate genes responsible for the entire program of unsaturated fatty acid biosynthesis in transgenic mouse liver. J Biol Chem 273:35299-35306

Stark KD, Salem N Jr (2005) Fast gas chromatography for the identification of fatty acid methyl esters from mammalian samples. Lipid Technol 17:181-185

Stefan N, Peter A, Cegan A, Staiger H, Machann J, Schick F, Claussen CD, Fritsche A, Haring HU, Schleicher E (2008) Low hepatic stearoyl-CoA desaturase 1 activity is associated with fatty liver and insulin resistance in obese humans. Diabetologia 51:648-656

Toda K, Takeda K, Akira S, Saibara T, Okada T, Onishi S, Shizuta Y (2001) Alternations in hepatic expression of fatty-acid metabolizing enzymes in ArKO mice and their reversal by the treatment with 17beta-estradiol or a peroxisome proliferator. J Steroid Biochem Mol Biol 79:11-17

Turyn J, Stojek M, Swierczynski J (2010) Up-regulation of stearoylCoA desaturase 1 and elongase 6 genes expression in rat lipogenic tissues by chronic food restriction and chronic food restriction/refeeding. Mol Cell Biochem 345:181-188

Voest EE, Rooth H, Neijt JP, van Asbeck BS, Marx JJ (1993) The in vitro response of human tumour cells to desferrioxamine is growth medium dependent. Cell Prolif 26:77-88

Wang J, Yu L, Schmidt RE, Su C, Huang X, Gould K, Cao G (2005a) Characterization of HSCD5, a novel human stearoyl-CoA desaturase unique to primates. Biochem Biophys Res Commun 332:735-742

Wang Y, Botolin D, Christian B, Busik J, Xu J, Jump DB (2005b) Tissue-specific, nutritional, and developmental regulation of rat fatty acid elongases. J Lipid Res 46:706-715 
Wang Y, Botolin D, Xu J, Christian B, Mitchell E, Jayaprakasam B, Nair MG, Peters JM, Busik JV, Olson LK, Jump DB (2006) Regulation of hepatic fatty acid elongase and desaturase expression in diabetes and obesity. J Lipid Res 47:2028-2041

Warensjo E, Sundstrom J, Vessby B, Cederholm T, Riserus U (2008) Markers of dietary fat quality and fatty acid desaturation as predictors of total and cardiovascular mortality: a populationbased prospective study. Am J Clin Nutr 88:203-209

Wu JH, Lemaitre RN, Imamura F, King IB, Song X, Spiegelman D, Siscovick DS, Mozaffarian D (2011) Fatty acids in the de novo lipogenesis pathway and risk of coronary heart disease: the Cardiovascular Health Study. Am J Clin Nutr 94:431-438

Yamazaki T, Okada H, Sakamoto T, Sunaga K, Tsuda T, Mitsumoto A, Kudo N, Kawashima Y (2012) Differential induction of stearoyl-CoA desaturase 1 and 2 genes by fibrates in the liver of rats. Biol Pharm Bull 35:116-120

Zhang F, Xu X, Zhou B, He Z, Zhai Q (2011) Gene expression profile change and associated physiological and pathological effects in mouse liver induced by fasting and refeeding. PLoS ONE 6:e27553 